\title{
Annual
} Review

$$
\begin{array}{r}
\text { of } \\
\text { Applied } \\
\text { Linguistics }
\end{array}
$$

1983 


\section{ANNUAL REVIEW of}

\section{Applied Linguistics}

\section{3}

Robert B. Kaplan: General Editor

University of Southern California

Alison d'Anglejan: Co-editor Université de Montréal

J Ronayne Cowan: Co-editor University of Illinois

Braj B. Kachru: Co-editor University of Illinois

G. Richard Tucker: Co-editor Center for Applied Linguistics

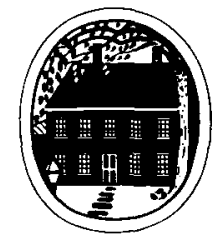

Newbury House Publishers, Inc. / Rowley / Massachusetts / 01969 ROWLEY - LONDON - TOKYO

1984 
The Annual Review of Applied Linguistics is published annually. This is the fourth annual volume, covering the 1982-1983 publication years.

General Editor: Robert B. Kaplan

Department of Linguistics

University of Southern California

Editorial Directors for $A R A L$ :

Alison d'Anglejan

Faculté des Sciences de l'Éducation

Université de Montréal

J Ronayne Cowan

Department of Linguistics

University of Illinois

Braj B. Kachru

Department of Linguistics

University of Illinois

G. Richard Tucker

Director

Center for Applied Linguistics 
This fourth volume of this annual series, like the preceding volumes which appeared in 1981,1982 , and 1983, is respectfully dedicated to the many professional Applied Linguists who were involved in helping to launch this publication, to those who helped formulate the framework for this and prior volumes, to those who have generously contributed to the series, and to all Applied Linguists and their students who, hopefully, will reap some benefit from its existence.

RBK 
The editors of this volume gratefully acknowledge the support of Newbury House Publishers in the preparation of this volume and the cooperation of the Department of Linguistics and the American Language Institute of the University of Southern California.

ISBN 0-88377-455-0

NEWBURY HOUSE PUBLISHERS, INC.

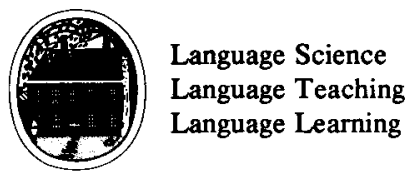

ROWLEY, MASSACHUSETTS 01969

ROWLEY - LONDON - TOKYO

Copyright ㄷ 1984 by Newbury House Publishers, Inc. All rights reserved. No part of this book may be reproduced or transmitted in any form or by any means, electronic or mechanical, including photocopying, recording, or by any information storage and retrieval system, without permission in writing from the Publisher.

Printed in the U.S.A.

First printing: October 1984

$\begin{array}{lllll}5 & 4 & 3 & 2 & 1\end{array}$




\section{CONTENTS}

Introduction

ix

Robert B. Kaplan

LITERACY: INTRODUCTORY ESSAY

On the Study of Literacy

David Bendor-Samuel

LITERACY ISSUES

Linguistics and Literacy

Gloria Kindell

Literacy in Monolingual Societies

Tej K. Bhatia

\section{REGIONAL SURVEYS}

Language and Literacy in West Africa

Eyamba G. Bokamba

Literacy in the Southern Sudan:

A Case Study of Variables Affecting Literacy Programs

J Ronayne Cowan

Literacy in South Asia

R. N. Srivastava

Reading: United States

Rose-Marie Weber

Literacy in Indonesia

Peter $\mathrm{H}$. Lowenberg

Literacy in Thailand

J. D. Palmer

APPLIED ASPECTS

Assessment

William C. Hall

Adult Literacy

JoAnn Crandall

BIOGRAPHIC INFORMATION ON CONTRIBUTORS

INDEXES

Author Index

Subject Index 